\title{
Seasonal variation in natural populations of Drosophila spp. (Diptera) in two woodlands in the State of São Paulo, Brazil
}

\author{
Felipe Rafael Torres \& Lilian Madi-Ravazzi
}

Instituto de Biociências, Letras e Ciências Exatas, Universidade Estadual Paulista, Departamento de Biologia, 15054-000 São José do Rio Preto, SP, Brasil. (lilian@ibilce.unesp.br)

\begin{abstract}
The composition and the seasonality of the natural populations of Drosophila species in relation to the climatic variables temperature and rainfall were analyzed from September 1998 through October 1999 by monthly collections, in two woodlands in the Northwest of the State of São Paulo, Brazil. The diversity dominance component curves were inclined, reflecting low diversity and high dominance of few species. Among the 25 species recorded, Drosophila sturtevanti Duda, 1927 was the most frequent and abundant. On the opposite to data in literature, D. paranaensis Barros, 1950 abundance and frequency were greater than those from $D$. mercatorum Patterson \& Wheeler, 1942. A positive correlation between abundance and rainfall was observed for D. nebulosa Sturtevant, 1916. These data are indicative of changes in the populations structure due to new adaptive strategies arised in response to environmental modifications.
\end{abstract}

KEYWORDS. Brazil, abiotic factors, seasonality, Drosophila, biodiversity.

RESUMO. Variação sazonal em populações naturais de Drosophila spp. (Diptera) em duas matas do Estado de São Paulo, Brasil. A composição e a sazonalidade de populações de Drosophila foram analisadas de setembro de 1998 a outubro de 1999 em coletas mensais realizadas em duas matas do noroeste do Estado de São Paulo, Brasil, considerando-se as variáveis climáticas temperatura e pluviosidade. As curvas do componente de dominância apresentaram-se inclinadas, refletindo uma baixa diversidade e uma alta dominância de poucas espécies. Drosophila sturtevanti Duda, 1927 foi a mais abundante e frequente das 25 espécies registradas. Em contraposição a dados da literatura, a abundância e a frequêencia de D. paranaensis Barros, 1950 foram maiores do que as de D. mercatorum Patterson \& Wheeler, 1942. Foi observada uma correlação positiva entre a abundância e a pluviosidade para D. nebulosa Sturtevant, 1916. Esses achados são indicativos de mudanças na estrutura das populações de Drosophila devido a novas estratégias adaptativas surgidas em resposta às modificações ambientais.

PALAVRAS-CHAVE. Brasil, fatores abióticos, sazonalidade, Drosophila, biodiversidade.

Populations are entities in a state of change. Even when the community and the ecosystem appear not to change, the density, mortality, survival, age distribution, growth rate and other attributes of the component populations generally fluctuate, as species adjust constantly to the seasons, physical forces and to each other. Consequently, it is much more revealing to discover in what way and how quickly a given population is changing than what its size and composition may be at a certain moment (ODum, 1988).

In the natural world, it is important to distinguish between seasonal changes in the size of a population, largely controlled by seasonal adaptations linked to environmental factors, and annual fluctuations. Annual fluctuations may be considered in two categories: those controlled principally by annual differences in extrinsic factors such as temperature and rainfall, which are beyond the sphere of population interactions, and intrinsic factors, oscillations controlled principally by population dynamics, like biotic factors, such as the availability of food or energy. In many cases, year-on-year changes in abundance appear to be clearly correlated to variation in one or more of the principle extrinsic limiting factors, but some species maintain such a regular relative abundance, apparently irrespective of obvious environmental factors, that the term "cycles" appears to be appropriate. Species that have such a regular variation in population size are often described as "cyclical". Populations modify and compensate for the perturbations of physical factors, thus, the more organized and mature the community, or the more stable the physical environment, or both, the less will be the amplitude of the fluctuations in population density over time (KREBS, 1985).

According to BRNCIC et al. (1985) the seasonality of each species in the natural world is the result of a long and continuous process of adaptation to environmental conditions in which the species usually lives.

Flies of the Drosophila genus are appropriate for the study of population fluctuation, as they are insects highly sensitive to slight environmental modifications, which are reflected in the size of natural populations. Studies of the population structure and ecology of Drosophila species have supplied important information, giving us a better understanding of their evolutionary process (BizZo \& SENE, 1982).

Thus, climatic conditions existing in different seasons of the year may be a critical factor in population fluctuation. It is known that changes in temperature and rainfall almost always affect vital parameters of Drosophila species such as viability, fertility, development time and other factors that influence the rate of population growth and survival. In addition, temperature affects the vigour of the flies and, therefore, the number of specimens that go towards the bait. Temperature, rainfall and light intensity also have an influence on the supply of resources, principally in 
relation to the periods of flowering and fruiting of various vegetable species which provide most of the sites for the community's oviposition and feeding (BRNCIC et al., 1985).

Biotic factors also influence the diversity and abundance of natural populations of Drosophila, including intra- and interspecific relationships, such as, population density, population age distribution, and the competition and relationships between drosophilids and their hosts and predators.

The number of individuals of a species in a locality is significantly influenced by the presence of other species, especially those that are ecologically related (e.g. Putman, 1995; Begon et al., 1996). As a result, genetic changes in the population reflect a response to changes caused by the presence or absence of other species. The ability to colonize multiple niches is an indication of the biological success of many species. Sympatric species usually compete with each other for a limited number of habitats within a geographical area. This competition, however, may be reduced by natural selection by means of specialization in the available niches (CUNHA et al., 1951).

The purpose of the this study is to contribute to the knowledge of the fauna of Drosophila and of the seasonal variation in the abundance of their populations with data correlated to temperature and rainfall, in two woodlands in the State of São Paulo in Brazil.

\section{MATERIAL AND METHODS}

The collections were made in two woodlands in the Northwest of the State of São Paulo - Brazil. One is a City Park (cerrado vegetation) located within the urban perimeter of the municipality of São José do Rio Preto (20²' $210^{\prime \prime}$ 'S, 49 $37^{\prime} 120^{\prime \prime} \mathrm{W}$; altitude $430 \mathrm{~m}$ ) and the other is a private fragment of semideciduous tropical forest situated $23 \mathrm{~km}$ from the municipality of Novo Horizonte (21 ${ }^{\circ} 32^{\prime} 148^{\prime \prime}$ 'S, $49^{\circ} 22^{\prime} 490^{\prime \prime} \mathrm{W}$; altitude $426 \mathrm{~m}$ ). In order to facilitate discussion of the data the abbreviations RP and $\mathrm{NH}$ will be used to refer to these two regions, respectively. Due to the large area of the Novo Horizonte woodland region, it was divided into two collecting points: NH1 and $\mathrm{NH} 2$. The area denominated $\mathrm{NH} 2$ is situated to the left/North of the Tietê river bank and area NH1 is $4 \mathrm{~km}$ from this point. In the area close to the river (NH2) there is greater space among trees due to a higher level of anthropic activity.

Twelve collections were carried out from September 1998 through August 1999 in the area of Rio Preto (RP), and from November 1998 to October 1999 in Novo Horizonte (NH1 and NH2). The flies were attracted by open traps suspended $1.70 \mathrm{~m}$ from the ground containing bait made of mature bananas and fresh biological yeast (Saccharomyces cerevisiae, Meyer \& Hansen, 1883). The traps are made of dark plastic bottles with an opening covered with a wire screen (C. R.Vilela, pers. comm.). In Rio Preto 5 traps were set, and in Novo Horizonte 8 traps, 4 near the river (NH2) and 4 away from the river (NH1). The traps were set two days prior to each collection.

The flies were captured with the aid of an entomological net, then transferred to tubes containing a banana culture medium and identified in laboratory.

The species were identified using specialized bibliography with descriptions and identification keys. The terminalia of collected male or male offspring of collected female were used to identify cryptic species.

The relationship between the abundance of the species, and richness, temperature (measured at the place of collection) and rainfall (registered by the meteorological organs of the region each month), was analyzed by means of the Spearman correlation coefficient $(r)$, to a level of significance of 5\% (ZAR, 1999). Diversity was calculated by the Shannon-Wiener index and equity or uniformity by the Pielou index (KreBs, 1999). Voucher specimens are deposited in the Museu de Zoologia, Universidade de São Paulo (MZSP).

\section{RESULTS AND DISCUSSION}

In addition to the Drosophila willistoni subgroup, 25 species were identified amongst a total of 24,595 flies collected, being 10,800 captured in the Rio Preto area (RP), 4,780 in the Novo Horizonte 1 area (NH1) and 9,016 in the Novo Horizonte 2 area (NH2) (Tabs. I-III).

Medeiros \& KLACKO (2004) using a closed trap for capture of drosophilids, recognized 125 species among 29,289 males analyzed in three areas of forests in the State of São Paulo. From them, 57.6\% were identified at the species level and 30 species found were absent from the previous species list for the State of São Paulo (TidonSkLORZ \& SEnE, 1999). Those authors attributed the high number of species found to the sensibility of the used methodology.

The species in the present study were classified into three groups according to their abundance, as follows: the species of group A are the most abundant, with percentage values over $10 \%$; the species of group B are those of intermediate abundance, with percentages from 1 to $10 \%$; and the species of group C, with low abundance, showing percentages lower than $1 \%$.

Drosophila sturtevanti Duda, 1927 and D. simulans Sturtevant, 1919 were included in group A in the three areas; D. malerkotliana Parshad \& Paika, 1964 was also included in this group in the RP area, as well as the willistoni subgroup in the NH1. Out of the total of flies collected in the three areas, around $75 \%$ are included in group A, from 7 to $25 \%$ in group B, and less than $5 \%$ in group $\mathrm{C}$, that showed the greatest number of species (Tabs. I-III).

Some species had intermediate abundance and $100 \%$ frequency in the collections, as the willistoni subgroup, D. paranaensis Barros, 1950 and $D$. polymorpha Dobzhansky \& Pavan, 1943 in the RP area and $D$. antonietae Tidon-Sklorz \& Sene, 2001 and $D$. buzzatii Patterson \& Wheller, 1942 in NH2 (Tab. IV).

Two additional drosophilids were also captured in our collections: Scaptodrosophila latifasciaeformis Duda, 1940 and Zaprionus indianus Gupta, 1970. From S. latifasciaeformis 265 individuals were collected in the RP, 190 in NH2 and 6 in NH1. In the collections made in the RP area, 152 specimens of $Z$. indianus were captured from March through August, five were captured in NH1 from August through October, and 53 individuals in $\mathrm{NH} 2$, from April through October.

There was no correlation between the total number of 
individuals captured in Rio Preto and temperature $(r=0.18)$ nor with the rainfall index $(r=0.28)$ (Figs. 1,2). The same was true for the NH1 area, for temperature $(r=0.23)$ and rainfall $(r$ $=0.39$ ), and in the NH2 area for temperature $(r=0.42)$ (Figs. $1,2)$. However, there was a correlation with the variation of the rainfall index $(r=0.74)$ in January, the month with the highest quantity of individuals $(2,864)$, was also the month with the highest rainfall index in the period $(464.5 \mathrm{~mm})$.

Most of the flies were captured in the hot rainy season (October through March), but a correlation was only observed in NH2 $(r=0.72)$.

A correlation was found between abundance and rainfall for $D$. sturtevanti, D. malerkotliana and the $D$. willistoni subgroup in RP, NH1 and NH2 (Figs. 3-5) and D. nebulosa Sturtevant, 1916 in NH2 (Fig. 6), and between abundance and temperature for D. mercatorum Patterson \& Wheeler, 1942 in RP(Fig. 7).

The NH2 area was the richest, with 21 species, followed by the RP area with 19 species, and NH1 with 18 species, in addition to the $D$. willistoni subgroup and repleta group, which were found in all the areas, and the saltans group in the $\mathrm{RP}$ and $\mathrm{NH} 2$ areas. A correlation between richness and temperature was found for the RP area $(r=0.717)$, and between richness and rainfall for the $\mathrm{NH} 2$ area $(r=0.602)$.

The greatest diversity (Shannon-Wiener index) and equitability (Pielou index) was found in RP, 0.73 and 0.54 , respectively. In NH1 the diversity index was 0.62 and the equity index was 0.48 . In the $\mathrm{NH} 2$ area, the diversity index was 0.71 and the equitability index was 0.51 .

DobZHANSKY \& PAVAN (1950) showed that rainfall appears to have a greater influence on the abundance of Drosophila populations than temperature, since an increase in rainfall produces an increase in flowering and fruiting, thus increasing the number of oviposition and feeding sites for the species.

The populations of $D$. sturtevanti and $D$. malerkotliana seem to be strongly influenced by rainfall, since the correlation between their abundance and the rainfall index was positive in the three areas. In the months of the dry season, the number of specimens of both species was significantly reduced.

The increase of $D$. sturtevanti population in the months at the end and beginning of the year was also observed by Tidon-SKLORZ \& SENE (1992) in relation to D. malerkotliana.

As shown in the literature, a positive correlation between rainfall and abundance has also been observed in the D. willistoni subgroup. The flies of this subgroup are frequently found in woodland regions, and are always registered in large numbers (PAVAN, 1959; SENE et al., 1980; ARAúJo \& VALENTE, 1981; Tidon-SKLORZ \&

Table I. Absolute number (n) of the species or group of species of Drosophila collected from September of 1998 through August of 1999 in Rio Preto area (RP). The species are classified in abundance order: GROUP A, more abundant; GROUP B, intermediate abundance; GROUP C, low abundance. *, Females (unidentified to species level).

\begin{tabular}{|c|c|c|c|c|c|c|c|c|c|c|c|c|c|c|}
\hline & Sep & Oct & Nov & Dec & Jan & $\mathrm{Feb}$ & Mar & Apr & May & Jun & Jul & Aug & & \\
\hline Taxon & $\mathrm{n}$ & $\mathrm{n}$ & $\mathrm{n}$ & $\mathrm{n}$ & $\mathrm{n}$ & $\mathrm{n}$ & $\mathrm{n}$ & $\mathrm{n}$ & $\mathrm{n}$ & $\mathrm{n}$ & $\mathrm{n}$ & $\mathrm{n}$ & TOTAL & $\%$ \\
\hline \multicolumn{15}{|l|}{ GROUP A } \\
\hline D. sturtevanti & 225 & 105 & 105 & 704 & 1,832 & 661 & 322 & 91 & 22 & 62 & 54 & 45 & 4,228 & 39.15 \\
\hline D. simulans & 208 & 81 & 47 & 110 & 26 & - & 07 & 04 & 11 & 164 & 1,014 & 936 & 2,608 & 24.15 \\
\hline D. malerkotliana & - & 05 & 98 & 632 & 255 & 137 & 126 & 71 & 32 & 46 & 72 & 04 & 1,478 & 13.69 \\
\hline \multicolumn{15}{|l|}{ GROUP B } \\
\hline willistoni subgroup* & 14 & 10 & 23 & 77 & 197 & 204 & 217 & 184 & 08 & 22 & 41 & 02 & 999 & 9.25 \\
\hline D. paranaensis & 27 & 54 & 226 & 53 & 18 & 02 & 03 & 03 & 04 & 81 & 219 & 116 & 806 & 7.46 \\
\hline D. polymorpha & 10 & 16 & 32 & 19 & 25 & 01 & 50 & 09 & 05 & 05 & 08 & 28 & 208 & 1.93 \\
\hline D. mercatorum & 30 & 06 & 57 & 12 & 29 & 01 & - & - & - & 01 & 08 & 24 & 168 & 1.56 \\
\hline \multicolumn{15}{|l|}{ GROUP C } \\
\hline repleta group* & 06 & 09 & 23 & 06 & 07 & - & 01 & - & 01 & 04 & 27 & 14 & 98 & 0.91 \\
\hline D. guaru & 02 & 04 & 12 & 03 & 01 & - & 02 & 06 & 05 & 13 & 07 & 01 & 56 & 0.52 \\
\hline D. austrosaltans & - & - & - & - & 12 & 09 & 02 & 04 & 02 & 02 & 06 & 02 & 39 & 0.36 \\
\hline D. prosaltans & 03 & 06 & 04 & 03 & 02 & 04 & 01 & 03 & - & - & 10 & 02 & 38 & 0.35 \\
\hline D. ararama & 03 & 01 & 06 & 03 & 02 & - & - & - & - & - & - & - & 15 & 0.14 \\
\hline D. mediopunctata & 01 & - & - & - & - & - & 05 & 05 & - & 02 & - & - & 13 & 0.12 \\
\hline saltans subgroup* & - & - & - & - & 02 & 06 & 02 & 01 & 01 & 01 & - & - & 13 & 0.12 \\
\hline D. immigrans & - & - & 01 & - & 02 & - & - & - & - & - & 02 & 06 & 11 & 0.10 \\
\hline D. nebulosa & - & 01 & 01 & 01 & 01 & 01 & - & - & - & 01 & - & - & 06 & 0.06 \\
\hline D. paramediostriata & - & - & 04 & - & - & - & & - & - & - & 02 & - & 06 & 0.06 \\
\hline D. melanogaster & 01 & - & - & - & - & - & - & - & - & - & - & 02 & 03 & 0.03 \\
\hline D. ananassae & 01 & 02 & - & - & - & - & - & - & - & - & - & - & 03 & 0.03 \\
\hline D. buzzatii & 01 & 01 & - & - & - & - & - & - & - & - & - & - & 02 & 0.02 \\
\hline D. hydei & - & - & - & - & - & - & - & - & - & - & - & 01 & 01 & 0.01 \\
\hline D. pallidipennis & - & - & - & - & - & - & - & - & - & - & - & 01 & 01 & 0.01 \\
\hline TOTAL & 532 & 301 & 639 & 1,623 & 2,411 & 1,026 & 738 & 381 & 91 & 404 & 1,470 & 1,184 & 10,800 & 100 \\
\hline
\end{tabular}


Table II. Absolute number (n) of the species or group of species of Drosophila recorded from November of 1998 through October of 1999 in Novo Horizonte-1 area (NH1). The species are classified in abundance order: GROUP A, more abundant; GROUP B, intermediate abundance; GROUP C, low abundance. *, Females (unidentified to species level).

\begin{tabular}{|c|c|c|c|c|c|c|c|c|c|c|c|c|c|c|}
\hline & Nov & Dec & Jan & Feb & Mar & Apr & May & Jun & Jul & Aug & Sep & Oct & & \\
\hline Taxon & $\mathrm{n}$ & $\mathrm{n}$ & $\mathrm{n}$ & $\mathrm{n}$ & $\mathrm{n}$ & $\mathrm{n}$ & $\mathrm{n}$ & $\mathrm{n}$ & $\mathrm{n}$ & $\mathrm{n}$ & $\mathrm{n}$ & $\mathrm{n}$ & TOTAL & $\%$ \\
\hline \multicolumn{15}{|l|}{ GROUP A } \\
\hline D. sturtevanti & 14 & 37 & 1,734 & 189 & 95 & 12 & - & 02 & 35 & 02 & 05 & 44 & 2,169 & 45.39 \\
\hline willistoni subgroup* & 14 & 114 & 522 & 144 & 525 & 33 & 07 & 03 & 156 & 01 & - & 10 & 1,529 & 31.99 \\
\hline $\begin{array}{l}\text { D. simulans } \\
\text { GROUP B }\end{array}$ & - & 99 & 28 & 01 & - & - & - & - & 79 & 186 & 49 & 53 & 495 & 10.36 \\
\hline D. malerkotliana & 05 & 03 & 180 & 20 & 29 & 03 & - & - & - & - & - & - & 240 & 5.02 \\
\hline D. polymorpha & 04 & 11 & 68 & 01 & 03 & 01 & - & - & 16 & 12 & - & 01 & 117 & 2.45 \\
\hline D. mercatorum & 03 & 02 & 33 & 01 & - & 01 & - & - & 07 & 13 & - & 01 & 61 & 1.28 \\
\hline $\begin{array}{l}\text { D. paranaensis } \\
\text { GROUP C }\end{array}$ & 10 & - & 01 & 03 & - & - & - & - & 08 & 01 & 24 & 03 & 50 & 1.05 \\
\hline D. nebulosa & - & 31 & 10 & - & - & - & - & - & - & - & - & - & 41 & 0.86 \\
\hline D. prosaltans & 06 & 03 & 01 & - & 02 & 02 & - & 01 & 05 & 01 & - & 04 & 25 & 0.52 \\
\hline repleta group* & 04 & 01 & - & - & 01 & - & - & - & 02 & - & 02 & 01 & 11 & 0.23 \\
\hline D. ararama & - & - & 05 & - & - & - & 01 & - & 02 & - & - & 02 & 10 & 0.21 \\
\hline D. buzzatii & - & 07 & 02 & - & - & - & - & - & - & - & 01 & - & 10 & 0.21 \\
\hline D. guaru & 04 & - & - & - & 01 & 01 & - & - & - & - & - & - & 06 & 0.13 \\
\hline D. paramediostriata & - & - & 02 & - & 01 & - & - & - & 02 & - & - & - & 05 & 0.10 \\
\hline D. immigrans & 01 & - & - & - & - & - & - & - & 01 & - & - & 01 & 03 & 0.06 \\
\hline D. coroica & - & - & 01 & - & - & - & - & 01 & 01 & - & - & - & 03 & 0.06 \\
\hline D. melanogaster & - & 01 & - & - & - & - & - & - & - & - & - & - & 01 & 0.02 \\
\hline D. mediopunctata & - & - & - & - & - & - & - & - & - & - & - & 01 & 01 & 0.02 \\
\hline D. ananassae & 01 & - & 01 & - & - & - & - & - & - & - & - & - & 02 & 0.02 \\
\hline D. austrosaltans & - & 01 & - & - & - & - & - & - & - & - & - & - & 01 & 0.02 \\
\hline TOTAL & 66 & 310 & 2,588 & 359 & 657 & 53 & 08 & 07 & 314 & 216 & 81 & 121 & 4,780 & 100 \\
\hline
\end{tabular}

1

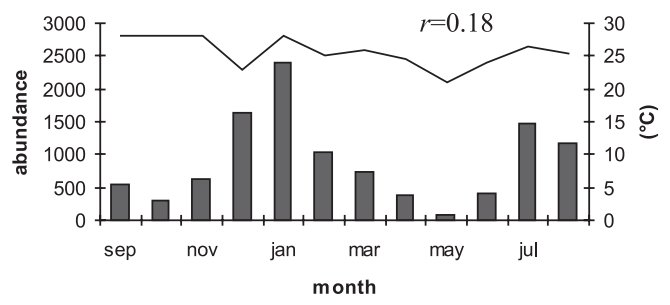

$\mathrm{NH} 1$

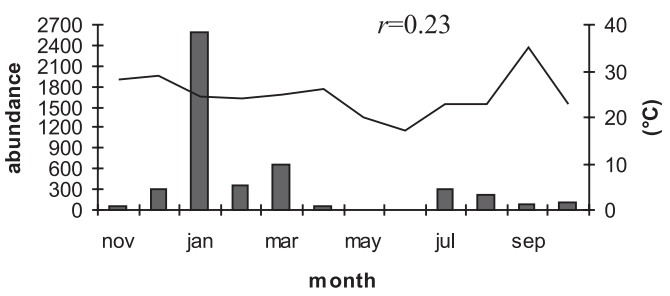

$\mathrm{NH} 2$

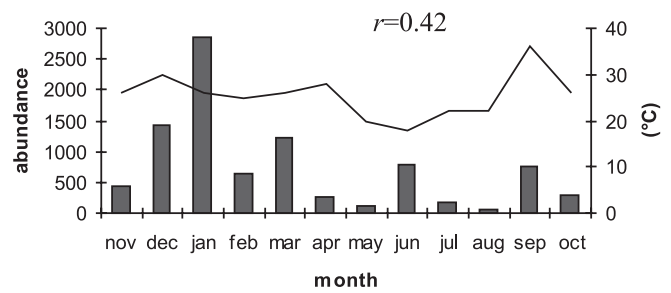

2
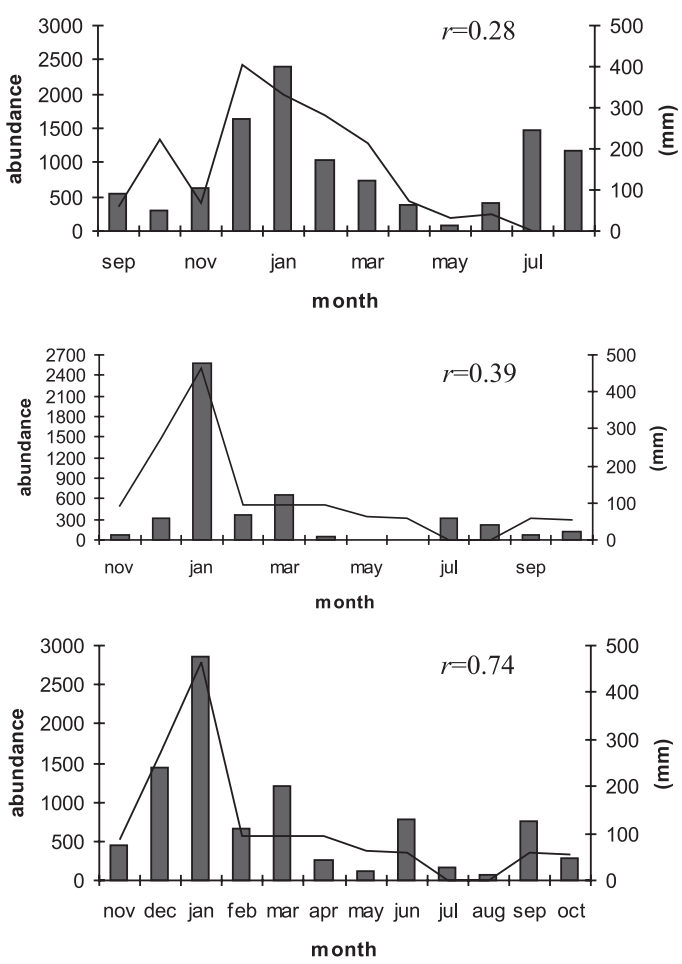

Figs. 1, 2. Total abundance of the Drosophila spp. in every month of collection in Rio Preto (RP), Novo Horizonte, area 2 (NH2) and area 1 (NH1) (1, abundance $\mathrm{X}$ temperature; 2, abundance $\mathrm{X}$ precipitation; $r$, correlation of Spearman). 
SENE, 1992). Low rainfall is considered a limiting factor for the species of this subgroup (SENE et al., 1980; Tidon-SKLorz \& SENE, 1992).

Drosophila simulans Sturtevant, 1919 was frequent in the three areas, however the fluctuation of the population was not associated with either temperature or rainfall. OCHANDO (1980) observed that increases in the population of $D$. simulans are associated with the transition of temperature between seasons. These results also suggest that seasonal changes may be influencing the preponderance of this species.

The only species for which there was a positive correlation between the number of flies captured and the temperature, in the RP area exclusively, was $D$. mercatorum. This species is highly generalist and is found in various phytogeographical formations, mainly in bushland (TIDON-SKLORZ et al., 1994).

VILELA et al. (1980), in a study of the fauna of drosophilids from Argentina, observed a greater incidence of D. mercatorum flies in less extreme environments. Even though RP is not an area of great abundance of the species, the observation of the mentioned authors may explain the positive correlation between abundance and temperature for D. mercatorum, since in this area the temperature was less variable than in the $\mathrm{NH}$ areas throughout the year.

Drosophila paranaensis, another species of the D. mercatorum subgroup (D. repleta group) was recorded in greater numbers than $D$. mercatorum in every collection. The high number of flies and the frequency of D. paranaensis contrast with the data of VILELA et al. (1983) and TidON-SKLORZ et al. (1994), which showed that D. paranaensis is not commonly found in the different morphoclimatic domains.

There are innumerable factors that may influence the species richness of a community. First, there are factors that may be referred to as geographical, for example, latitude and longitude. A second group of factors may be correlated with the productivity of the environment (an environment with a greater variety of niches would be able to host a greater variety of species), the climatic variability, age and rigidity of the environment. A third group of factors refers to biological attributes. Relationships of predation, competition and population density, amongst others, may have important consequences on the number of species in a given locality (BEGON et al., 1996).

In temperate and cold zones, Drosophila

Table III. Absolute number (n) of the species or group of species of Drosophila recorded from November 1998 to October 1999 in Novo Horizonte-2 area (NH2). The species are classified in abundance order: GROUP A, more abundant; GROUP B, intermediate abundance; GROUP C, low abundance. *, Females (unidentified to species level).

\begin{tabular}{|c|c|c|c|c|c|c|c|c|c|c|c|c|c|c|}
\hline & Nov & Dec & Jan & Feb & Mar & Apr & May & Jun & Jul & Aug & Sep & Oct & & \\
\hline Taxon & $\mathrm{n}$ & $\mathrm{n}$ & $\mathrm{n}$ & $\mathrm{n}$ & $\mathrm{n}$ & $\mathrm{n}$ & $\mathrm{n}$ & $\mathrm{n}$ & $\mathrm{n}$ & $\mathrm{n}$ & $\mathrm{n}$ & $\mathrm{n}$ & TOTAL & $\%$ \\
\hline \multicolumn{15}{|l|}{ GROUP A } \\
\hline D. sturtevanti & 50 & 193 & 2,659 & 376 & 487 & 10 & - & 05 & 05 & - & - & 45 & 3,830 & 42.48 \\
\hline D. simulans & 14 & 942 & 80 & 67 & 100 & 100 & 74 & 553 & 56 & 40 & 656 & 202 & 2,884 & 31.99 \\
\hline \multicolumn{15}{|l|}{ GROUP B } \\
\hline D. polymorpha & 81 & 20 & 18 & 19 & 118 & 35 & - & 74 & 43 & 06 & 65 & 18 & 497 & 5.51 \\
\hline D. malerkotliana & 02 & 25 & 02 & 103 & 330 & 10 & 02 & 16 & - & - & - & - & 490 & 5.43 \\
\hline D. mercatorum & 100 & 22 & 32 & 09 & 19 & 09 & 01 & 20 & 16 & 06 & - & 12 & 246 & 2.73 \\
\hline D. buzzatii & 47 & 49 & 23 & 02 & 02 & 38 & 04 & 11 & 09 & 05 & 20 & 06 & 216 & 2.40 \\
\hline willistoni group* & - & 36 & 01 & 36 & 126 & 06 & - & 05 & - & - & - & - & 210 & 2.33 \\
\hline repleta group* & 23 & 29 & 24 & 11 & 07 & 18 & 09 & 21 & 09 & 03 & 02 & 02 & 158 & 1.75 \\
\hline D. antonietae & 03 & 01 & 05 & 09 & 13 & 22 & 12 & 62 & 14 & 01 & 01 & 02 & 145 & 1.61 \\
\hline D. paranaensis & 103 & 02 & 01 & 01 & 01 & - & 03 & 13 & 08 & 01 & - & 05 & 138 & 1.53 \\
\hline D. nebulosa & - & 112 & - & 02 & 03 & 01 & 01 & 01 & - & - & - & - & 120 & 1.33 \\
\hline \multicolumn{15}{|l|}{ GROUP C } \\
\hline D. melanogaster & - & 02 & 01 & - & 04 & 03 & 01 & 02 & - & 01 & 03 & - & 17 & 0.19 \\
\hline D. paramediostriata & - & - & - & 12 & - & - & - & - & - & - & - & - & 12 & 0.13 \\
\hline D. nigricruria & 09 & - & - & - & 01 & - & - & - & - & 01 & - & - & 11 & 0.12 \\
\hline D. prosaltans & - & 05 & - & 03 & - & 01 & - & - & - & - & - & - & 09 & 0.10 \\
\hline D. hydei & 02 & - & 04 & - & - & - & - & 01 & 02 & - & - & - & 09 & 0.10 \\
\hline D. immigrans & - & - & - & - & - & - & - & 02 & 04 & - & - & - & 06 & 0.07 \\
\hline D. pallidipennis & 04 & - & - & - & 01 & - & - & - & - & - & - & - & 05 & 0.06 \\
\hline D. ararama & 02 & - & - & - & 01 & - & - & - & - & - & - & - & 03 & 0.03 \\
\hline saltans subgroup* & - & - & 01 & - & 02 & - & - & - & 01 & - & - & - & 04 & 0.04 \\
\hline D. fuscolineata & - & - & - & - & - & - & - & 02 & - & - & - & - & 02 & 0.02 \\
\hline D. busckii & - & - & - & - & - & - & - & - & 01 & - & - & 01 & 02 & 0.02 \\
\hline D. canalinea & - & - & - & - & - & - & - & 01 & - & - & - & - & 01 & 0.01 \\
\hline D. coroica & - & - & - & - & - & - & - & - & - & - & - & 01 & 01 & 0.01 \\
\hline TOTAL & 440 & 1,438 & 2,851 & 650 & 1,215 & 253 & 107 & 789 & 168 & 64 & 747 & 294 & 9,016 & 100 \\
\hline
\end{tabular}


populations are profoundly affected by radical changes in the natural environment produced by the alternation of the seasons, with the result that the relative frequency of different species changes from month to month. In tropical areas, especially in Brazil, changes in the environment are caused by the alternation between the dry and rainy seasons (Dobzhansky \& PAVAn, 1950).

The greater species richness encountered in $\mathrm{NH} 2$ may be due to two main factors: a more diverse vegetation, and the proximity of the Tietê river, creating a more heterogeneous environment. The occurrence of a large number of Cactaceae in the $\mathrm{NH} 2$ woodland contributed to the appearance of those species of the repleta group which are associated with cactaceous plants, like $D$. antonietae and D. buzzatii (VILELA et al., 1983; TiDONSkLorz \& Sene, 1992; Tidon-Sklorz et al., 1994). The $\mathrm{NH} 1$ and RP areas shared more characteristics, both being classified as bushcountry (N. Taroga-Ranga, pers. comm.).
The three areas also presented differences in relation to the variables temperature and rainfall. In RP, species richness seems to be related to temperature; the number of species in each month corresponded directly to the increase or diminution in the temperature. In NH1, there was no correlation between species richness and either of the climatic variables. Probably another factor, unidentified yet, is influencing species richness in this area. On the other hand, in $\mathrm{NH} 2$, there was a correlation between species richness and rainfall. It should be emphasized that the months with the greatest species richness occur during the rainy season. These differences show that the three areas have distinct support capacities for the several Drosophila species.

The Shannon-Wiener index $\left(\mathrm{H}^{\prime}\right)$ revealed a greater diversity in the $\mathrm{RP}$ area, although in $\mathrm{NH} 2$ a greater number of species was collected. This may be more easily understood if we observe the quantity and dominance of each species in the three areas, since the index combines
RP

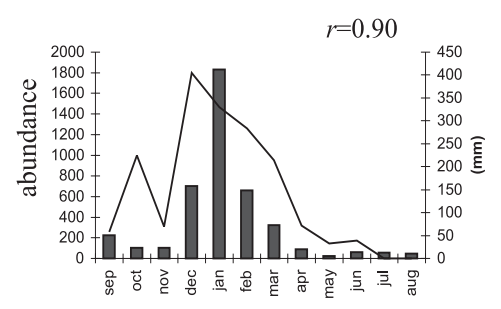

4

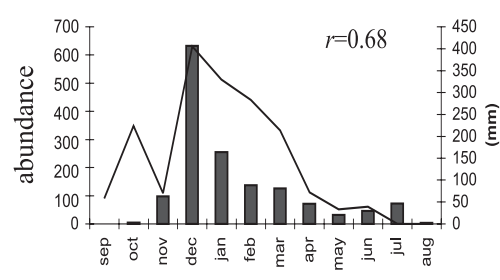

5 年

NH 1

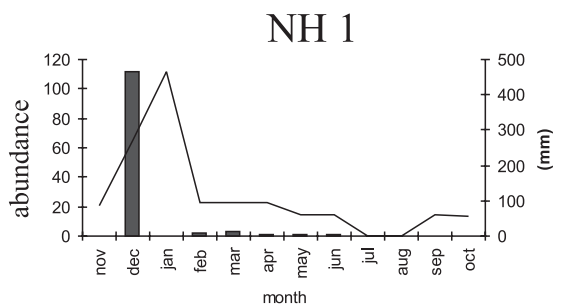

NH 1
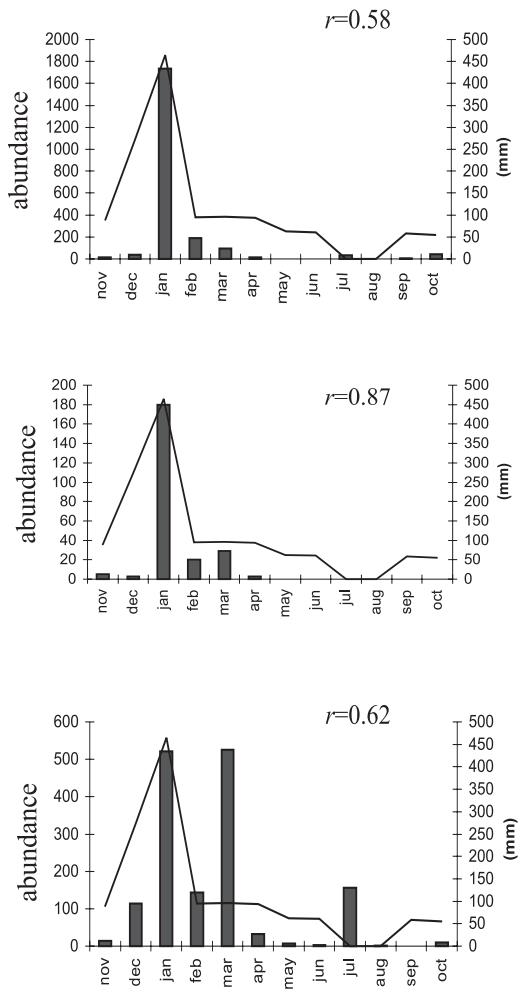

NH 2
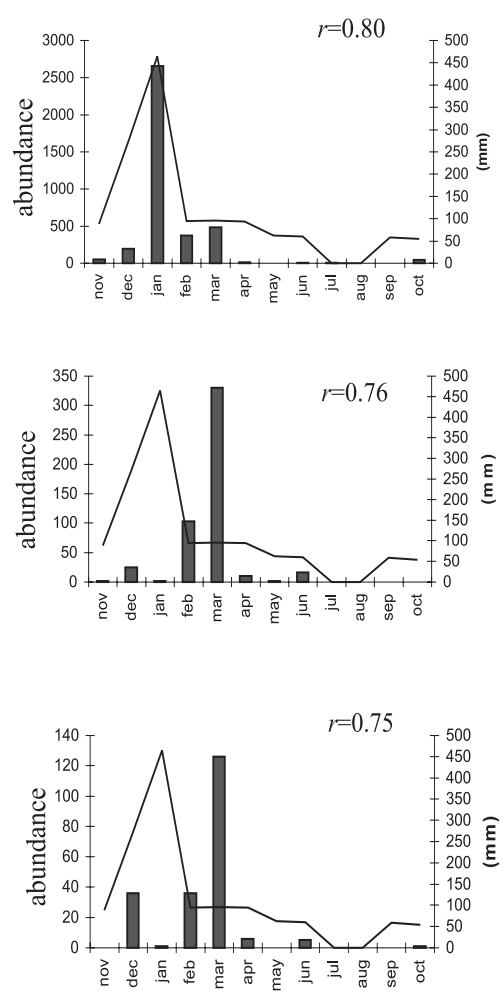

RP

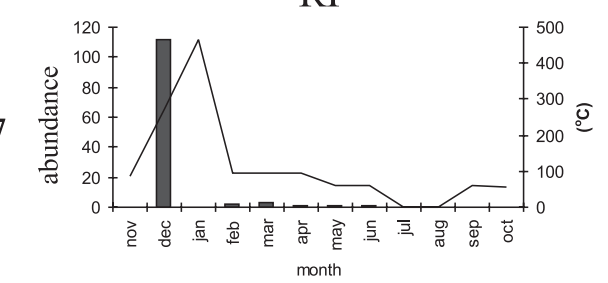

Figs. 3-7. Positive correlation between the abundance and the climatic variables in the three areas in study: 3, D. sturtevanti; $4, D$. malerkotliana; 5, willistoni subgroup; 6, D. nebulosa; 7, D. mercatorum; Figs. 3-6, frequency X precipitation; Fig. 7, frequency X temperature ( $r$, correlation of Spearman). 
two functions: number of species and uniformity, i.e. the number of individuals presented in each species (LUDWIG \& ReYNOLD, 1988). Most of the flies collected in NH2 were concentrated in just two species, D. sturtevanti and D. simulans, which together represent $79.9 \%$ of the whole sample collected. In RP, despite a lower number of species, there was a greater equitability in the distribution of individuals, which was confirmed by the Pielou index.

Discussions in the literature suggest that some observations of population fluctuations may be due to sampling errors, such as the type of trap and bait used. However there are variations which can not be attributed to random factors. It is unknown whether such variations are the result of the adaptation of populations to the external environment, or whether they result from internal regulation mechanisms. In any case, periodic changes in population size have an evolutionary significance, since they may alter the genetic composition and the structure of the populations. The introduction of invasive species such as Zaprionus indianus, a drosophilid recently introduced into Brazil (VILELA et al., 2001), which has spread rapidly, may have a significant influence on the populations of native species. Although the abundance of this species was not significant during the collection period in the present study, recent data of our laboratory confirm a surprising expansion and abundance of this species in the regions studied (unpublished data) and in other localities (DE Toni et al., 2001; Tidon et al., 2003), which may interfere in population dynamics and favour new evolutionary strategies.

Table IV. Absolute frequency (n) and percentage (\%) of the number of time in that each species or group of species occurred in twelve collections. The species are grouped in relation of the level of frequency; GROUP A, the more frequent; GROUP B, the intermediary frequent and GROUP C, the less frequent; RP, São José do Rio Preto/SP; NH1 and NH2, Novo Horizonte/SP; D. ana, D. ananassae Doleschall, 1858; D. ant, D. antonietae Tidon-Sklorz \& Sene, 2001; D. ara, D. ararama Pavan \& Cunha, 1947; D. aus, D. austrosaltans Spassky, 1957; D. bus, D. busckii Coquillet, 1901; D. buz, D. buzzatii Patterson \& Wheeler, 1942; D. can, D. canalinea Patterson \& Mailand, 1944; D. cor, D. coroica Wasserman, 1962; D. fus, D. fuscolineata Duda, 1925; D. gua, D. guaru Dobzhansky \& Pavan, 1943; D. hyd, D. hydei Sturtevant, 1921; D. imm, D. immigrans Sturtevant, 1921; D. mal, D. malerkotliana Parshad \& Paika, 1964; D. med, D. mediopunctata Dobzhansky \& Pavan, 1943; D. mel, D. melanogaster Meigen, 1830; D. mer, D. mercatorum Patterson \& Wheeler, 1942; D. neb, D. nebulosa Sturtevant, 1916; D. nig, D. nigricruria Patterson \& Mailand, in Patterson, 1943; D. pal, D. pallidipennis Dobzhansky \& Pavan, 1943; D. par, D. paranaensis Barros, 1950; D. para, D. paramediostriata Townsend \& Wheller, 1955; D. pol, D. polymorpha Dobzhansky \& Pavan, 1943; D. pro, D. prosaltans Duda, 1927; rep group, repleta group; sal subgroup, saltans subgroup; D. sim, D. simulans Sturtevant, 1919; D. stu, D. sturtevanti Duda, 1927; wil subgroup, willistoni subgroup.

\begin{tabular}{|c|c|c|c|c|c|c|c|c|}
\hline \multicolumn{3}{|c|}{$\mathrm{RP}$} & \multicolumn{3}{|c|}{ NH1 } & \multicolumn{2}{|c|}{$\mathrm{NH} 2$} & \multirow[b]{2}{*}{$\%$} \\
\hline Taxon & $\mathrm{n}$ & $\%$ & Taxon & $\mathrm{n}$ & $\%$ & Taxon & $\mathrm{n}$ & \\
\hline GROUP A & & & GROUP A & & & GROUP A & & \\
\hline D. stu & 12 & 100.0 & D. stu & 11 & 91.7 & D. stu & 09 & 75.0 \\
\hline D. sim & 11 & 91.7 & wil subgroup & 11 & 91.7 & D. sim & 12 & 100.0 \\
\hline \multirow[t]{2}{*}{ D. mal } & 11 & 91.7 & D. $\operatorname{sim}$ & 07 & 58.3 & & & \\
\hline & & & & & & GROUP B & & \\
\hline GROUP B & & & GROUP B & & & D. pol & 11 & 91.7 \\
\hline wil subgroup & 12 & 100.0 & D. mal & 06 & 50.0 & D. mal & 08 & 66.7 \\
\hline D. par & 12 & 100.0 & D. pol & 09 & 75.0 & D. mer & 11 & 91.7 \\
\hline D. pol & 12 & 100.0 & D. mer & 08 & 66.7 & D. buz & 12 & 100.0 \\
\hline \multirow[t]{2}{*}{ D. mer } & 09 & 75.0 & & & & wil subgroup & 06 & 50.0 \\
\hline & & & GROUP C & & & rep group & 12 & 100.0 \\
\hline GROUP C & & & D. neb & 02 & 16.7 & D. ant & 12 & 100.0 \\
\hline rep group & 10 & 83.3 & D. par & 07 & 58.3 & D. par & 10 & 83.3 \\
\hline D. gua & 11 & 91.7 & D. pro & 09 & 75.0 & D. neb & 06 & 50.0 \\
\hline D. aus & 08 & 66.7 & rep group & 06 & 50.0 & & & \\
\hline D. pro & 10 & 83.3 & D. ara & 04 & 33.3 & GROUP C & & \\
\hline D. ara & 05 & 41.7 & D. buz & 03 & 25.0 & D. mel & 08 & 66.7 \\
\hline D. med & 04 & 33.3 & D. gиа & 03 & 25.0 & D. par & 01 & 8.3 \\
\hline sal subgroup & 06 & 50.0 & D. para & 03 & 25.0 & D. nig & 03 & 25.0 \\
\hline D. imm & 04 & 33.3 & D. imm & 03 & 25.0 & D. pro & 03 & 25.0 \\
\hline D. neb & 06 & 50.0 & D. cor & 03 & 25.0 & D. hyd & 04 & 33.3 \\
\hline D. para & 02 & 16.7 & D. mel & 01 & 8.3 & D. imm & 02 & 16.7 \\
\hline D. mel & 02 & 16.7 & D. med & 01 & 8.3 & D. pal & 02 & 16.7 \\
\hline D. ana & 02 & 16.7 & D. ana & 02 & 16.7 & D. ara & 02 & 16.7 \\
\hline D. buz & 02 & 16.7 & D. aus & 01 & 8.3 & sal subgroup & 03 & 25.0 \\
\hline D. hyd & 01 & 8.3 & & & & D. fus & 01 & 8.3 \\
\hline \multirow[t]{3}{*}{ D. pal } & 01 & 8.3 & & & & D. bus & 02 & 16.7 \\
\hline & & & & & & D. can & 01 & 8.3 \\
\hline & & & & & & D. cor & 01 & 8.3 \\
\hline
\end{tabular}


Acknowledgments. To Dra. Denise Rossa Feres (Departamento de Zoologia, UNESP/IBILCE) for critically reading earlier versions of the manuscript and Dr. Peter James Harris (Departamento de Letras Modernas, UNESP/IBILCE) and Dra. Hermione E. M.de C. Bicudo (Departamento de Biologia, UNESP/IBILCE) for improving the English version; to $\mathrm{CNPq}$ for a fellowship given to F. R. Torres and to FUNDUNESP and CAPES for financial support.

\section{REFERENCES}

Araújo, A. M. \& Valente, V. L. S. 1981. Observações sobre alguns lepidópteros e drosofilídeos do Parque Turvo, RS. Ciência e Cultura 33:1485-1490.

Begon, M.; Harper, J. L. \& Townsend, C. R. 1996. Ecology: individual, populations and communities. Cambridge, Blackwell. 945p.

Bizzo, N. M. V. \& Sene, F. M. 1982. Studies on the natural populations of Drosophila from Peruibe (SP) Brazil (Diptera, Drosophilidae). Revista Brasileira de Biologia 42:539-544.

BRNCIC, D.; BudNiK, M. \& Guines, R. 1985. An analysis of a Drosophilidae community in Central Chile during a three years period. Zeitschrift für Zoologische Systematik und Evolutionsforschung 23:90-100.

Cunha, A. B. Da; Dobzhansky, Th. \& Sokoloff, A. 1951. On food preferences of sympatric species of Drosophila. Evolution 5:97-101.

De Toni, D. C.; Hofmann, P. R \& Valente, V. L. 2001. First record of Zaprionus indianus (Diptera, Drosophilidae) in the State of Santa Catarina, Brazil. Biotemas 14:71-85.

DobZhansky, T. \& PAVAN, C. 1950. Local and seasonal variations in relative frequencies of species of Drosophila in Brazil. Journal of Animal Ecology 19:1-14.

KREBS, C. J. 1985. The experimental analysis of distribution and abundance. 3ed. New York, Harper and Row. 800p.

1999. Ecological methodology. 2ed. Menlo Park, Addison Wesley. 620p.

Ludwig, J. A. \& Reynolds, J. F. 1988. Statistical ecology: a primer on methods and computing. New York, John Wiley and Sons. 337p.

Medeiros, H. F. \& KLaczko, L. B. 2004. How many species of Drosophila (Diptera, Drosophilidae) remain to be describe in the Forest of São Paulo, Brazil? Species lists of three forest remnants. Biota Neotropica 4(1). Disponível em: <http:// www.bioneotropica.org.br/v4n 1/pt/abstrat?article+ BN01604012004>. Acesso em: 30.06.2005.

Ochando, D. 1980. Seasonal distribution of Drosophila species. Experientia 36:163-164.

Odum, E. P. 1988. Ecologia. Rio de Janeiro, Guanabara. 432p.

Pavan, C. 1959. Relações entre as populações de Drosophila e o meio ambiente. Boletim da Faculdade de Filosofia Letras e Ciências Humanas da Universidade de São Paulo, Biologia Geral, 11:1-81.

Putman, R. J. 1995. Community ecology. London, Chapman and Hall. 178p.

Sene, F. M.; Val, F. C.; Vilela, C. R. \& Pereira, M. A. Q. R. 1980. Preliminary data the geographical distribution of Drosophila species within morphoclimatic domains of Brazil. Papéis Avulsos de Zoologia 33:315-326.

Tidon-Sklorz, R. \& Sene, F. M. 1992. Vertical and temporal distribution of Drosophila (Diptera, Drosophilidae) species in a wooded area in the state of São Paulo, Brazil. Revista Brasileira de Biologia 52:311-317.

1999. Drosophila. In: Brandão, C. R. F. \& Cancello, E. M eds. Biodiversidade do Estado de São Paulo, Brasil, Síntese do conhecimento ao final do século XX: Invertebrados terrestres. São Paulo, FAPESP. v. 5, p.247-261.

Tidon, R.; Ferreira-Leite, D. \& LeÃo, B. F. D. 2003. Impact of the colonisation of Zaprionus (Diptera, Drosophilidae) in different ecosystems of the Neotropical Region: 2 years after the invasion. Biological Conservation 112:299-305.

Tidon-Sklorz, R.; Vilela, C. R.; Sene, F. M. \& Pereira, M. A. Q. R. 1994. The genus Drosophila in the Serra do Cipó. Revista Brasileira de Entomologia 39(3/4):627-637.

Vilela, C. R.; Pereira, M. A. Q. R. \& Sene, F. M. 1983. Preliminary data on the geographical distribution of Drosophila species within morphoclimatic domains of Brazil. II. The repleta group. Ciência e Cultura 35:66-70.

Vilela, C. R.; Sene, F. M. \& Pereira, M. A. Q. R. 1980. On the Drosophila fauna of Chaco and east slopes of the Andes in Argentina. Revista Brasileira de Biologia 40:837-841.

Vilela, C. R.; Teixeira, E. P. \& Stein, C. P. 2001. Mosca-Africanado-Figo, Zaprionus indianus (Diptera: Drosophilidae). In: Vilela, E. F.; Zucchi, R. A.; Cantor, F. eds. Histórico e impacto das pragas introduzidas no Brasil. Ribeirão Preto, Holos. p.48-52.

ZAR, J. H. 1999. Biostatistical analysis. New Jersey, Prentice Hall. 663p.

Recebido em junho de 2005. Aceito em julho de 2006. ISSN 0073-4721

Artigo disponível em: www.scielo.br/isz 